\title{
Redemption: The Repayment of Fines and the Reintegration of Exiles
}

\begin{abstract}
The second of two main chapters, this analyses the redemption of exiles and what this can tell us about the values of late medieval Kampen society concerning morally acceptable behaviour. The first section concerns the practical aspects around the reintegration of banished individuals from all categories, whereas the second section focuses specifically on the financial arrangements between exiles and magistrates which allowed the former to return to Kampen. The final section discusses the links between debt and morality, in order to establish whether defaulting public debtors were banished because they were considered to have displayed immoral behaviour.
\end{abstract}

Keywords Redemption $\bullet$ Debt $\bullet$ Morality $\bullet$ Crime

In Kampen, as in Ulm, there must have been banished offenders who did not stray too far from the town, as they either still had property there, a family, a business with customers that needed to be tended to, or a steady position. These people would have tried, most likely generally with assistance from people inside Kampen, to gather money to be able to pay off their fines or debts, or to negotiate terms with the town representatives.

E. Frankot, Banishment in the Late Medieval Eastern Netherlands, https://doi.org/10.1007/978-3-030-88867-1_5 
For those in debt, ${ }^{1}$ to be allowed back was relatively straightforward: the fines or debts needed to be paid off. For those banished as a punishment, the situation was potentially more fluid, especially for those sentenced to an exile of undetermined duration. Those banished for life or for an extensive period (five or ten years) would most likely have moved away to try their luck elsewhere. For others, though, it would have been worthwhile not to stray too far from Kampen to try and negotiate a return. As mentioned above, some were banished until their conduct improved, or until they were invited to return. This chapter looks in more detail at the processes of reintegration for both groups of exiles, with a specific focus on the financial arrangements made for the payment of fines.

\section{Returning TO THE FOLD}

A few cases offer some information concerning the redemption of exiles after banishment as a punishment and their return to town. Dirk Witte was banished on 1 July 1473 at a distance of four miles after he had spoken badly about 'lords, princes, ladies and young women' and had been caught pairing off men and women for illegal sexual acts. He swore an oervede oath that he would stay at least four miles from Kampen until 'he [was] informed otherwise' ('men hem anders weten laat'). On 10 May 1474 he was allowed to return to town on condition that he would behave himself from now on, on pain of eternal banishment at a distance of six miles. ${ }^{2}$ Goiken Henricsz was banished in 1476 for various acts of misbehaviour, for which he was imprisoned first. He swore an oath to remain at a distance of at least ten miles from Kampen on pain of losing his hand. An added note indicates that Goiken was a mariner. It says that in case he came within the ten-mile radius as a result of bad weather at sea, he should attempt to leave again as soon as possible. Goiken was allowed to return to Kampen in December 1478, so at least two years later, on condition that he stop his misbehaviour. ${ }^{3}$ So these two men were allowed to return to the fold after having spent a significant amount of time outside the

\footnotetext{
${ }^{1}$ The word 'debt' (singular) as in 'to owe a debt' or 'to be in debt' is here also used to indicate the money owed to the town as a result of the non-payment of fines (as is 'debtor' as someone owing that money), in addition to the more usual meaning of 'debts' as money owed as a result of any kind of exchange (including rents) or of a loan. The word 'debts' (plural) is here only used to indicate the latter.

${ }^{2}$ DV, f. 125r (1 Jul 1473); Reg, p. 12 (1473); LC, f. Iv (10 May 1474).

${ }^{3}$ Reg, p. 14 (1476); LC, f. 8v (December 1478).
} 
town, and on condition that they refrain in the future from the behaviour which got them in trouble in the first place. Dirk Witte is likely the same as the man by the same name that became a citizen in $1467 .{ }^{4} \mathrm{He}$ also appears regularly as a creditor and as a legal representative of others in the sources of the late 1470s and early 1480s, so he seems to have been a man of some financial means. Nonetheless, his offences had been considered so severe that he had been banished at a distance of four miles and had not been allowed back for more than ten months. After his return, however, he appears to have become a full member of Kampen society again, lending out money and being asked to act on other people's behalf. ${ }^{5}$ There is no evidence that his status or reputation was affected by his crime or his banishment. Witte redeemed himself through his banishment.

Goiken Henricsz was a mariner, a profession which required men to be away from home for extensive amounts of time. In addition, it was a profession that could be undertaken from any port. This would most likely have made a banishment from one of these ports easier to bear. It seems unlikely that being banished affected Goiken's chances of finding work, and the Kampen magistrates apparently agreed, considering it likely that he might end up near the town on a ship in need, as they specifically allowed for this possibility. The fact that Goiken was allowed back more than two years later suggests that he had some connections in Kampen which made it worthwhile for him to go through the effort of a court procedure. Unfortunately, none of these cases specify how the magistrates tracked down the exiles or communicated with them. In some cases, as is also suggested by a single entry in 1462 , messengers were sent out, who may have acquired information from family or friends with regard to where the outcast might be found. ${ }^{6}$ In other cases, the procedure will have been initiated by the exile seeking to return.

Even better recorded is the case of Dirk Sandersz and Suetken, who are also portrayed next to one of the entries in the Digestum Vetus (see Fig. 5.1). Dirk appears to have had dark hair and a beard, whereas Suetken is shown holding up her hand (like Hille in Fig. 4.3?), though it is unclear what this gesture might indicate. In September 1459 they were found guilty of double adultery, meaning that both parties were married to

${ }^{4} \mathrm{BB}$, f. $134 \mathrm{v}$ (1467).

${ }^{5}$ SR, f. $3 \operatorname{lr}(1475)$; LT, f. $114 \mathrm{v}$ (1485); SAK, RA, no. 75, f. 47v (4 November 1476) and f. $57 \mathrm{r}$ (9 June 1477).

${ }^{6}$ Reg, p. 6: 'eeir men hem baden sendt'. 


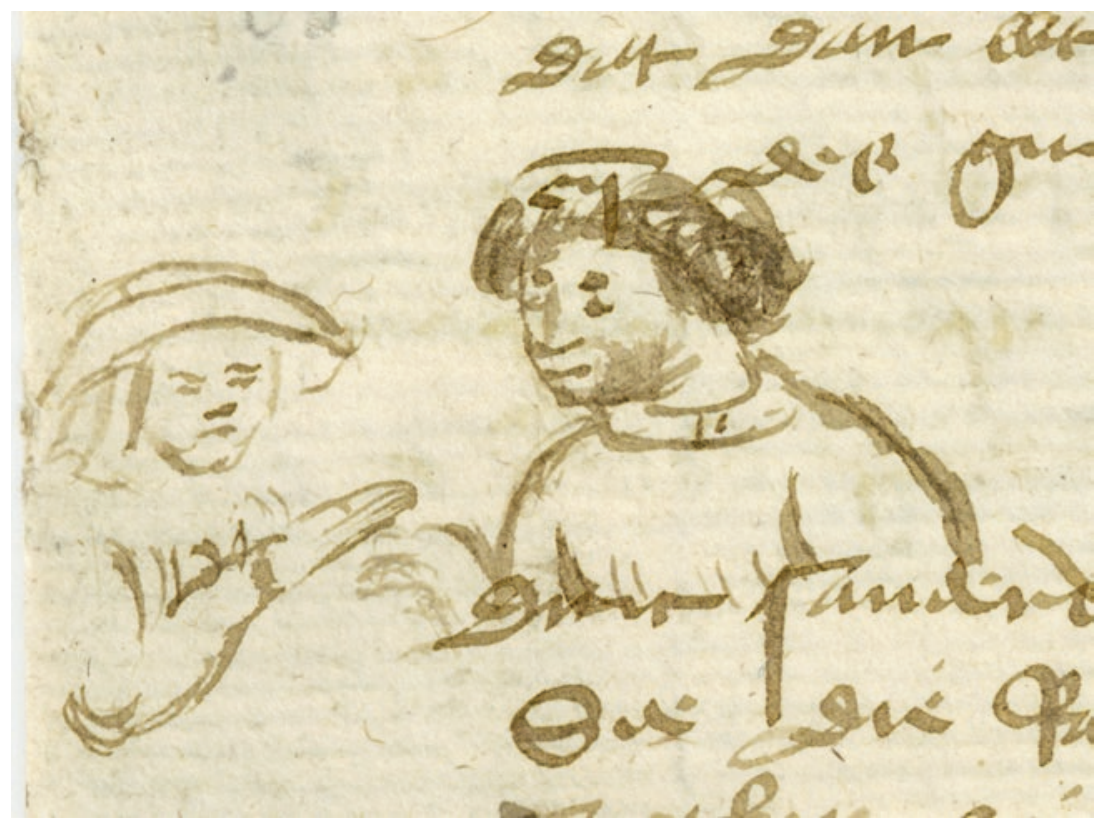

Fig. 5.1 Suetken and Diric Sandersz (DV, f. 34r (27 September 1459)). (C) Stadsarchief Kampen, Nederland/C City Archives Kampen, the Netherlands)

another person when they committed adultery. They were sentenced to banishment. Only four weeks later, on 25 October, Dirk had been readmitted and was back in court, where he promised not to have any more to do with Suetken. He also vouched to live peacefully with his wife Hille and to share his meals and his bed with her as a good husband should ('mit Hillen synen echten wyve restlich ende vredelic leven sal ende mit haer to mete ende to male gaen, ende to bedde als een guet man mit sijnen wijve schuldich is toe gaene'). ${ }^{7}$ On 13 November of the same year a note was added to this entry that Suetken had been readmitted too, under the same conditions.

The story does not end there. In 1467 Dirk Sandersz was banished again, at a distance of one mile, as is evident from an oath in the oerveden been in court for insulting the market master. DV, f. 26r (7 April 1457). 
register, though it is unclear why. ${ }^{8}$ At the start of 1468 Dirk was back in court, perhaps returning from his banishment. This time he was told that he would not be allowed to farm any of the town's fishing rights or conduct any trade on the fish market, but only directly from his house. He was told again to act like a husband to his wife Hille. In addition, he was disallowed to go into the courthouse, except on business, and would no longer be allowed to act as a witness. The reason for all this was that he had broken his oath, possibly that made in 1459 on his return to Kampen. Any future misbehaviour would result in lifelong banishment. ${ }^{9}$

In 1473, finally, Suetken (by then a widow) was back in court, having been readmitted after another banishment. The reason for the banishment had been that Dirk Sandersz had been found in her house. This time she was warned that if they would be caught again, she would be declared forfeit of all her goods within the freedom of Kampen. ${ }^{10}$ There is no mention of a sentence for Dirk in the Digestum Vetus, but there is another oath in the oerveden register from that same year in which he promised to stay away from Kampen at a distance of four miles. ${ }^{11}$ There is no mention whether this banishment was meant to be permanent, in accordance with the 1468 warning. From his appearance in other sources from December 1474 onwards, it appears that he was not permanently banished. In 1478 , his wife Hille was named as his widow, so he must have died in 1477 or 1478. Judging by the sources, Dirk Sandersz was likely a man of some financial means and standing, possibly a fish merchant, and a citizen. ${ }^{12}$ As such, the magistrates would probably have preferred not to exclude him permanently from their midst despite his regular perceived immoral behaviour. Nonetheless, they gave out a clear message that such behaviour was not acceptable by banishing Dirk at least three times. Unfortunately, we do not know how long the second and third banishments were and whether they got increasingly longer, for example. It is notable that Dirk's first banishment was shorter than that of his female partner. By allowing Dirk (and Suetken) back into the fold on a number of occasions, the magistrates could display their mercy and their willingness to reintegrate those

${ }^{8}$ Reg, p. 9 (1467).

${ }^{9}$ DV, f. $77^{\text {bis }}$ ( 30 January 1468$)$.

${ }^{10} \mathrm{DV}$, f. 130r (28 September 1473).

${ }^{11}$ Reg, p. 12 (1473).

${ }^{12}$ There does not appear to be a record of a Dirk Sandersz in the 'burgerboek'. He appears as a creditor in a number of documents, as does Hille, for example in SAK, RA, no. 75, f. 17r (2 December 1474). Hille appears as Dirk's widow in SAK, RA, no. 76, f. 34v (14 May 1478). 
who chose to better their lives. It is likely that the magistrates expected humility and contrition on the part of the former exiles, though there is no evidence of any rituals of reintegration. The magistrates did, at least temporarily, take away some of Dirk Sandersz's rights, but this was a result of him breaking his oath, rather than of the adultery itself, or of the banishment. And despite this, Dirk continued to be able to trade.

Looking back on the case of Suetken and Dirk today it may appear sad that their (love) affair, which lasted for at least 15 years, had such grave repercussions on their lives. Of course, we also should take into account the possibility that Dirk stalked and sexually harassed Suetken for more than 15 years. ${ }^{13}$ The Kampen magistrates in the fifteenth century were especially concerned with keeping the peace. Long-term extra-marital affairs could potentially cause a breach of the peace or other problems, such as those related to the existence of any illegal offspring and inheritances. In the second half of the fifteenth century the question of immorality also increasingly became a factor when judging such affairs. This was influenced by the already mentioned preaching of Observant friars like Brugman and by an increase of denunciations for adultery. ${ }^{14}$ As was elaborated upon in the previous chapter, this focus appears to have become more pronounced in the final quarter of the fifteenth century. This change is also reflected in the language that the magistrates used.

Other clues with regard to the return of outcasts can be found in the banishment register itself. As we know, this register mainly concerns banishment for debt (including the non-payment of fines), rather than banishment as a punishment. Of 1267 people recorded there between 1447 and 1500,410 entries (32.4 per cent) were crossed out, meaning that the entries were no longer valid. Though occasionally evidence points to other reasons for entries becoming obsolete, the vast majority of them were

${ }^{13}$ I am grateful to Christine Ekholst and other contributors to the 'Confronting Sexual Violence' roundtable at the International Medieval Congress in Leeds in 2019 for pointing out that we should not necessarily take the legal terminology of sexual crimes in court records at face value. What is termed 'fornication' (or 'adultery' for that matter) may have been rape in actual fact.

${ }^{14}$ Brand and Frankot, 'Das Kampener Stadtbuch', 53; Carlier, Kinderen van der minne?, 106-110; Carlier and Stabel, 'Questions de moralité', 256, 258-60. For a similar development in Italy under influence of friars like Bernardino, see Dean, Crime and Justice in Late Medieval Italy, 138, 154. Concerning aspects of property and adultery, see also Crawford, European Sexualities, 148-50. 
most likely deleted because the debt was paid off. ${ }^{15}$ We know for certain that they were paid with regard to about a third of entries that were deleted since 1465 ( 105 out of 316 people between 1465-1500) as their protagonists appear in the jaarkeur register as having arranged a repayment scheme with the town magistrates. We will focus on this group in more detail in the next section.

Although it is evident that Kampen's administration was not faultless (a number of entries were left undeleted despite the exiles appearing in the jaarkeur register settling their debt), it is likely that the majority of the remaining two-thirds of 1276 outcasts did not return from their banishment. ${ }^{16}$ One is said to have died. ${ }^{17}$ This could be because they were unable or unwilling to pay off their fines in order to be allowed to re-join the Kampen community. ${ }^{18}$ It is also possible that some were not given an opportunity by the town council to redeem themselves. As was clear from the oerveden register, a few of the individuals who were ousted following some time in custody for the non-payment of their fine were banished from Kampen permanently (see Chap. 4). It is likely that many of these groups of exiles had no close connections to the town and were itinerant workmen (or women), some of whom may have been cast out of other communities. Instead of troubling themselves with settling large fines in order to return to a place where they would never receive full citizenship privileges, if they were even allowed this, they are likely to have tried to start anew in another town. Others would have turned (or returned) to a life on the road. The sharing of information between towns (see Chap. 4) might, of course, have restricted options somewhat.

The worst cases of such itinerant outcasts can be found in the Digestum Vetus and the register of capital and corporal punishment. There we find long confessions, detailing thefts, robberies and murders conducted in

\footnotetext{
${ }^{15}$ For example, Jorgen Rijnscher, banished in 1475 following his flight after having committed some acts of violence, was flogged in 1478, which appears to have been considered sufficient to pay off his fine after a three-year banishment (Reg, p. 124); Coert Keest, Herman Wachter, Aernt Coster and Dirk Blome 'carried candles' in 1492 to make amends for the illegal chopping of wood (Reg, p. 142); in 1464 Mijnte carried the stone for a fine of $180 \mathrm{lb}$., a highly unusual display of mercy by the town magistrates (Reg, p. 103).

${ }^{16}$ The relevant counterparts of 12 of 105 entries of the jaarkeur have not been deleted in the banishment register. The administration appears to have gotten more accurate in the second half of the period (see also below): ten entries are from the 1465-1482 period, only two from the 1483-1500 period.

${ }^{17}$ Reg, p. 120 (1474).

${ }^{18} \mathrm{Cf}$. Zaremska, Les bannis au Moyen Âge, 160.
} 
various regions of the Low Countries, northern France and western Germany. These confessions, as mentioned before most likely admitted to under duress (though they had to be confirmed in court to become valid as evidence), ${ }^{19}$ were all made by visitors to Kampen. The confessors were generally executed. The already mentioned Hendrik die Cruyser, for example, confessed to having been banished from Utrecht, wounding a man in Deventer who subsequently died, as well as committing other woundings, possibly in Kampen as that is where he was eventually beheaded in $1483 .{ }^{20}$ Hans Oesterling confessed to several thefts, many conducted with others, in a large area covering much of the Netherlands and the north-east of Germany: Groningen, Friesland, Harderwijk, Utrecht, Purmerend, Haarlem, Leiden, Den Haag, Scheveningen, Delft, Gouda, Dordrecht, Brouwershaven, Arnemuiden, Middelburg, Vlissingen, Sluis, Bremen, Stade and other places, including Kampen where he tried to steal a wooden statue from St Nicholas church. He was beheaded, perhaps symbolically, on Saint Nicholas' Eve 1469. ${ }^{21}$ It is such cases that highlight the potentially very negative consequences of a banishment for both individuals and the urban community, and the difficulty some individuals had in redeeming themselves.

Of many men and women, we do not know where they ended up, as looking for them would mean searching through the sources of many Dutch, German and Belgian towns in case they ended up in court elsewhere. Occasionally there is a chance encounter with a former Kampen inhabitant: in Leiden in 1494 Hendrik Hoeymaker was arrested. It was known that he had been banished (probably in absentia) from Kampen after a manslaughter. He was eventually allowed to stay in Leiden after a large payment was made which may have been used to settle the case with the victim's family or to settle the fine with the Kampen authorities. ${ }^{22}$ It may well be that this payment would also have allowed him to return to Kampen. The fact that the Leiden authorities knew of the Kampen manslaughter, and that the Kampen magistrates had details of many crimes

\footnotetext{
${ }^{19}$ For example, in 1493 Geert van Walsem in court retracted his confession that he murdered four merchants with three other men. He was still drawn and broken on the wheel for several thefts and robberies with murder. Reg, p. 235 (10 Jun 1493).

${ }^{20}$ Reg, p. 226 (17 March 1483).

${ }^{21}$ DV, f. 95r (5 December 1469).

${ }^{22}$ Glaudemans, Om die wrake wille, 202. Glaudemans does not mention the possibility that the money may have been used for settling the fine. I have as yet been unable to locate this manslaughter in the Kampen sources.
} 
committed elsewhere as evidenced in the confessions by those sentenced to death, confirms that a lively correspondence was conducted between the towns in the Netherlands and its bordering regions. ${ }^{23}$ The case also suggests that individuals were able to find a home elsewhere after a banishment, especially when they had professions sought after in a particular town.

As it is difficult to gain a complete picture of the social circumstances of the offenders who were banished, it is also hard to get a clear profile of the people who were able to return to Kampen compared to those who were not. It is likely that among the former group were more outcasts who had citizenship, more who owned property or a business, and more who had a family and a social network in Kampen. As will become clear in the following section, a network of people who could stand surety for the payments that a reintegrating outcast had to pay was vital to be able to set up a financial arrangement with the town. In that respect it is perhaps surprising to note that relatively few offenders for whom a profession is recorded in the banishment register arranged to pay their fine in instalments. The vast majority (127 out of 149 for whom we know a profession) appears to have left Kampen for good. For example, of 19 fullers registered as banished, only 1 appears to have returned, of 15 weavers only 3 , and of 10 tailors also just 3 . The textile producing business appears to have been one with a high turnover of staff, presumably employing relatively many newcomers to the town. The same turnover can be recognised among the millers, where only one out of ten returned (and one died), and smiths of whom none came back of nine who were banished.

A possible reason for the relatively high percentage of offenders with a named profession who did not seek to come back to town is that relatively many people who did not originate in Kampen were identified by additional characteristics such as their profession or their place of origin. It may be that others who appeared in the sources did not need any further identification because they were known inhabitants of Kampen. Though Kampen was a reasonably sizeable town by medieval standards, it is likely that most people knew each other in a population of about $6000-8500$. And, as has already been argued, people without strong links to the town were more likely to try out their luck elsewhere after banishment. It is

\footnotetext{
${ }^{23}$ Concerning correspondence about criminal activities, see also Coy, Strangers and Misfits, 11; Vanhemelryck, Misdadigers tussen recht en beul, 26; Zaremska, Les bannis au Moyen Âge, 90-91, 163.
} 
likely that men with professions like textile workers, tailors, smiths and millers would have had no trouble finding work elsewhere (assuming their status as an exile did not interfere with this). That offenders without strong links to Kampen were less likely to return is also suggested by the fact that not one of the exiles who were identified by a geographical name sought reintegration.

Nonetheless, Kampen, like most medieval towns, was a place inhabited by many newcomers. The extant register of citizens, which unfortunately ends in 1469, includes many men, and some women, who gained citizenship after having migrated to Kampen from other places in the Low Countries and neighbouring German regions. An analysis of the register for the 50 years from 1420 to 1469 suggests that it does not include the sons of already existing citizens. None of the established Kampen families who supplied councillors and aldermen appear in the register, for example. These sons perhaps became citizens automatically or their registration was seriously flawed. ${ }^{24}$ Others had to pay to become burghers, and a by-law of 1485 laid down (or perhaps confirmed an already existing rule) that the children of the people who applied to become citizens also became citizens (on payment of a fee, of course). If the parents did not want this, none of them would be allowed to gain citizenship. ${ }^{25}$ It is noteworthy that the by-law speaks of 'olders' (parents), not just of the father. Women could and did on occasion become burghers and there are examples of mothers with sons (or daughters) becoming citizens. On the other hand, at least up until 1469, it was normally only the sons of the family who were registered in the Burgerboek with their fathers, so we should perhaps not read too much into the gender-unspecific terminology used in this by-law.

In the 50 years from 1420 to 1469,2608 new citizens were registered, approximately 52 per annum. In some years, such as 1445 and 1453 close to a hundred new burghers were accepted. This does not generally include the wives or daughters who, no doubt, had also come along to live in Kampen, nor those who did not pay for citizenship. Of these 2608 people, 66 or 67 were women, so just over one per year. Occasionally these were widows, presumably of deceased burghers, but others were clearly

${ }^{24}$ Prak (Citizens without nations, 34) confirms that the registration of born citizens elsewhere was also incomplete and that they appear to have often taken their citizenship for granted.

${ }^{25} \mathrm{DN}$, f. $35 \mathrm{v}(1485)$. 
migrants, such as Balyaene Hermansdochter of Quadebrede and Herman Swane, her son. ${ }^{26}$

As was suggested in Chap. 2, there do not appear to have been any restrictions in place on becoming a citizen in Kampen. Not many of the names are accompanied by a profession, but those that are (103 of them) include a variety of craftsmen. Strangely, in 1468, eight millers were accepted in a single year. ${ }^{27}$ Those that include a placename (303 entries) also show a wide geographical spread, from some of the larger towns in the bordering German lands, such as Bremen, Münster and Osnabrück, to those in the Low Countries (Groningen, Amersfoort, Utrecht, Dordrecht, Zierikzee and Den Bosch, for example) to towns and villages closer by. Many came with children: 410 were fathers (or mothers) with at least one son (or daughter) registered at the same time. Some were very large families indeed: nine men had five sons each and two had six. Johan Wolff, who gained citizenship in 1425, even brought along nine sons: Wolf, Arnt, Evert, Wyllem, Esken, Cracht, Alfer, another Wyllem and Johan. ${ }^{28}$

It is unclear whether there were any residence requirements prior to a person becoming a citizen..$^{29} \mathrm{~A} 1559$ ordinance suggests that it might have been possible to acquire citizenship on arrival, as long as a person could submit evidence of good reputation, the proper Christian religion ('van gueden Christlicken geloven ende doechdeliken erberen leven ende sonder quade fame van enige moetwillige feijten offte heresien sijn') and no history of manslaughter. The ordinance had been issued because, apparently, 'many strange, foreign and unknown' ('vrembde, uutheimische ende unbecande') people were thronging to Kampen wanting to buy citizenship and make use of the common pasture lands. New citizens needed to realise, however, that there was a requirement to actually live in the town. ${ }^{30}$ It is likely that if migrants could buy citizenship on arrival at this time,

${ }^{26} \mathrm{BB}, \mathrm{f} .104 \mathrm{r}(1423)$.

${ }^{27}$ As there is no specific evidence of many millers having been banished in previous years, this may have had something to do with the extension of the town which had started around 1462 .

${ }^{28} \mathrm{BB}$, f. $105 \mathrm{r}$.

${ }^{29}$ The answer to this can probably be found in F.C. Berkenvelder, Stedelijk burgerrecht en burgerschap. Een verkennende inventarisatie in Deventer, Kampen en Zwolle (1302-1811) (Zwolle 2005), but I came across this title too late to be able to access it for this publication.

30 'Die vrije ordinantie ... vanden ingecofften burgers ende die in burgers gemoede sitten' (21 February 1559), in: Overijsselsche Stad-, Dijk-en Markeregten, 237-41, specifically 238. 
when the magistrates were obviously concerned about the number of aliens knocking on the town gates and about their religion, they would most likely also have been able to do this in the second half of the fifteenth century. That does not mean that all migrants immediately became citizens. It is likely that most lived in the town for a while to establish themselves before applying for citizenship.

This openness to migrants able to pay for citizenship rights suggests that the town was doing fine economically and could use additional productive members of society. This was no doubt also to fill up gaps left as a result of a high urban mortality rate and an average 26-27 banishments per year, of which only about a third returned, as we have seen. One of the downsides of banishment was, of course, that it might rid the town of useful people. Citizenship does not seem to have been restricted to a small group, and many craftsmen were citizens, as were some members in the service industry, such as porters. The porters had their own guild and, according to a 1500 by-law, the town magistrates allowed that only two out of three guild masters needed to be burghers because not so many of them were. ${ }^{31}$ That the porters were relatively well-respected members of society is also clear from the fact that a number of them appear as guarantors for the people arranging to pay their fine in instalments. ${ }^{32}$

All of this suggests that the town magistrates were not principally against, or suspicious of, outsiders. Quite the contrary: there was a healthy influx of newcomers every year. Over 50 new (mostly male) citizens were accepted every year, most likely bringing along another 50 female family members on average. Of course, some of these new citizens would have already been living in Kampen. Moreover, there were those who could not afford to become citizens, but were attracted by job opportunities. In addition, the town was frequented by merchants and skippers from elsewhere.

Another hint that the magistrates did not seek to restrict access to the Kampen community to productive members of society is the fact that they facilitated offenders redeeming themselves by arranging financial terms. Again, the social circumstances of those seeking reintegration in this way are not easy to establish. Of the ones whose profession is mentioned in the

${ }^{31} \mathrm{DN}$, f. $5 \mathrm{lv}$.

${ }^{32}$ For example, Albert Jansz who appears a couple of times as a guarantor. Reg, p. 407 (1493), p. 410 (1494). 
banishment register, a variety of craftsmen are included, as well as two servants, a fisherman, a parson and a head boatswain. It is likely that the same variety existed among those whose professions we do not know. In the jaarkeur register, a similarly varied group can be found, though again the numbers are small: the profession of only 26 of the debtors who had been banished before they arranged to pay their fine is known. It is perhaps noteworthy that 9 of these 26 were Rhine skippers, but the share of Rhine skippers in this register is relatively high anyway: of 68 professions of debtors named in total, 12 were Rhine skippers, and 30 of 135 guarantors were too. No other profession comes close to being as prominent in this register as this group of men who were relatively prone to violence, but who also had a guild, an extensive network and some wealth and social standing.

There does not appear to be a marked difference between the varied social status of the people who arranged for the payment of their fine immediately and those who did so after a banishment. Both groups include servants, a variety of craftsmen and skippers. The only group that may be lacking is that of the wealthiest citizens who had probably been able to pay a fine outright. But a sample analysis of the lists of fines and other sources from 1490 shows that there were very few who could afford to pay the highest fines immediately. Of 156 fines which appear to have been paid immediately, the majority were smaller fines of $20 \mathrm{~s}$. (21 fines), $100 \mathrm{~s}$. (17 fines) and 2 (hern?) lb. (64 fines). ${ }^{33}$ Of the fines for woundings, only two were paid outright: one of $100 \mathrm{lb}$. and one of $200 \mathrm{lb} .{ }^{34}$ The others, at least 19 including 2 homicides, ended up arranging the payment of their fines in instalments or they were banished. ${ }^{35}$ There was also one person who arranged to pay his fine of $200 \mathrm{lb}$. for adultery in instalments. ${ }^{36}$ The difference between offenders who immediately arranged for the payment of a fine, and those who did not and ended up having to negotiate their return to the city after they had probably mostly fled the town, was probably small. The difference may mainly have been one of the circumstances of the offence and its aftermath. But, as previously noted, we know very little about the sequence of events that led to so many becoming outcasts after

${ }^{33} \mathrm{LT}$, ff. 143r-144r, 160r-161v, 163r; SR, ff. 18lv-183v.

${ }^{34}$ SR, f. 182r (Claes Allertsz 25 hern lb.); LT, f. 143r (Johan Glynchagen 50 hern lb.).

${ }^{35}$ Not all the entries in the lists of fines that indicate a banishment specify an offence, and some cannot be found in any of the other sources.

${ }^{36} \mathrm{LT}, \mathrm{f} .143 \mathrm{r}$ and SR, f. $182 \mathrm{r}$. 
fineable offences. We know more about what happened when such outcasts were able to negotiate their return, which is the subject of the next section.

\section{Financial Arrangements Between Town and Exiles}

About a third of the men and women who ended up as outcasts because of unpaid fines or debts did come back to Kampen after they had arranged for a payment in terms with the magistrates. From at least 1465, these financial arrangements were recorded in the jaarkeur register. Between 1465 and 1500, the register concerns 281 persons. Of these, 104 can also be found in the register of banishments. The rest likely arranged for payment of their fines on conviction, rather than being banished for failure to pay (or fleeing before their trial). These offenders had perhaps been better able to secure sureties from family members and friends or perhaps had a better reputation among the magistrates, and they had not panicked on having committed their offences. For example, in 1486 Andries Vierholt was fined 50 hern $\mathrm{lb}$. for wounding someone at night. It was arranged that he would pay his fine in five terms, the first one in 1486. Seven men stood surety for him. ${ }^{37}$ Vierholt was a man of some means who also rented town properties, for some of which he had to pay more than 50 hern lb. annually. ${ }^{38}$ But there were also people of lower social status, such as Geertken Jansdochter, a maidservant who managed to pay off a 20 hern $\mathrm{lb}$. fine in just two instalments. The register details that she had already paid the first. It would have been likely that her employers stepped in to assist her, but she only had one person standing surety for her, and it was not her boss. ${ }^{39}$ So it is unclear how this woman managed to bring together this significant sum of money in such a short period.

Nearly two-thirds of the outcasts who negotiated a financial arrangement with the magistrates did so in the year in which they had been banished, and 25 did in the following calendar year. Few of the entries in the banishment register are dated precisely, so it is not possible to determine the exact times that people spend outwith the town. Only in 11 cases did exiles take longer in trying to negotiate a return. Most likely these people

\footnotetext{
${ }^{37}$ Reg, p. 391 (October or November 1486); LT, f. 115v (1486).

${ }^{38}$ For example, SR, f. $173 \mathrm{v}$ (1490): one rental of $281 / 2 \mathrm{lb} .25 \mathrm{pl}$. paid in one term, and one of $67 \mathrm{lb} .18 \mathrm{pl}$. paid in two terms.

${ }^{39} \mathrm{Reg}$, p. 404.
} 
tried their luck elsewhere first, or actually moved somewhere else, before deciding that they wanted or needed to return after all. Two offenders returned about two years after their banishment, four exiles three years later and one each four and five years after having left. There are three outcasts who appear not to have come back for a long time, though we should take into account the possibility that a first return and second exile are missing from the records. On the other hand, the fines in these three cases add up. In 1478 Henric Palmer arranged to pay for a $100 \mathrm{lb}$. fine, a fine that appears to date back to $1465 .^{40}$ Even more extreme are the cases of Hessel Petersz and Herman Schuefstake who returned after about 22 and 23 years respectively. Schuefstake's fines, $100 \mathrm{lb}$. for a wounding plus $2 \mathrm{lb}$., add up exactly to those he was banished for in 1467. Petersz was banished for a $100 \mathrm{lb}$. fine in 1463 and paid off 25 hern lb. in $1485 .{ }^{41}$

But, as said, mostly offenders negotiated their return to Kampen within a year of their banishment (or flight) and most likely within a few weeks or months, as there was likely no other impediment to their return beyond the payment of the fine. On the other hand, seeing that the magistrates offered the possibility to arrange to pay off fines in instalments, there must have been other factors in play when an offender chose to flee. Most likely this was to escape any potential wrath from the victim and/or his or her relatives. Also, in cases of wounding, an offender may not necessarily have known whether or not his victim survived or would survive, and in cases of manslaughter a reconciliation usually needed to take place before a culprit could be welcomed back into the community. ${ }^{42}$ Finally, offenders may have been worried about being subject to a flogging, like a few of the individuals recorded in the oerveden register were (see Chap. 4).

As soon as a financial arrangement was agreed upon with an exile, the entry in the register of banishments was deleted. The deletion did not depend upon the full payment of the fine. This was similar to the practice in the Prussian towns of Kulm and Thorn where the entry concerning an exile was deleted within eight days of the agreed return to town, though

\footnotetext{
${ }^{40}$ Reg, p. 382 (12 July 1478).

${ }^{41}$ Petersz: Reg, p. 102 (1463), p. 358 (9 July 1485); Schuefstake: Reg, p. 108 (1467), Reg, p. 404 (December 1490).

${ }^{42}$ At least, according to the 1385 by-law. BvR, f. $22 \mathrm{v}$ (1385). The 1426 by-law does not specify whether a reconciliation was still required in addition to the $400 \mathrm{lb}$. fine. GB, f. $48 \mathrm{r}$ (1426). See also Chap. 4.
} 
there this was usually after a compensation payment was made in full. ${ }^{43}$ In Kampen, most of the payments were ultimately paid in full, after which the entry in the jaarkeur register was also deleted. There are a few examples of cases in which the full amount due was not paid. These entries remained undeleted in the jaarkeur register, but the relevant entries in the banishment register were crossed out. For example, Jan Tymansz was deemed a fugitive and exile after he had wounded a man on a ship during daytime in $1495 .{ }^{44}$ This crime was subject to a fine of $100 \mathrm{lb} . / 25$ hern lb. In 1496 Tymansz arranged to pay off his debt in eight instalments: 4 hern lb. to be paid during the reign of the current aldermen, and then 3 hern lb. every year until the fine was paid in full (the final term was in 1503). The notes on payments in the margins reveal that Tymansz paid his first six terms, but not the last two. ${ }^{45}$ It is not clear why not. Perhaps he died or moved elsewhere. In 1487 Johan Starke was due a fine of 25 hern lb., 10 of which he paid in cash straight away (perhaps on his return to Kampen). The rest would be paid in five terms of $3 \mathrm{lb}$. Starke never paid these terms and the jaarkeur states that he died. ${ }^{46} \mathrm{He}$ did not die straight away, though, as the annual jaarkeur lists in the town accounts from 1492, 1493 and 1494 noted that he was still due the remainder of several terms, and had sworn an oath to pay these. ${ }^{47}$ Unfortunately, the account does not go beyond 1494, so that we do not have an exact year of his death. Up until 1494 Starke was perhaps urged to pay, but may have been unable. No measures to evict him from the town appear to have been undertaken.

Another case of non-payment sheds some light on the procedure of arranging readmission into the town community. Stijne Tade had appeared in court twice in 1484. At the end of August, she was forbidden to draw any more beer, on punishment of $40 \mathrm{lb} .{ }^{48}$ Between 9 and 15 September she was back in court, but this time on much heavier charges: facilitating illegal sexual acts ('quade herberg'), keeping bad company at night and by day and generally leading an immoral life. As a punishment she was made to stay away from the town at a distance of at least one mile, on

\footnotetext{
${ }^{43}$ In these towns, the punishment for a wounding was the cutting off of the hand (as it had been in Kampen originally for a wounding at night), but this could usually be compensated, hence the need to pay a compensation in full. Jeziorski, 'Die Strafe der Ausweisung', 37-9.

${ }^{44}$ Reg, p. 145 (1495).

${ }^{45}$ Reg, p. 409 (1496).

${ }^{46}$ Reg, p. 393 (9 June 1487).

${ }^{47}$ SR, f. 205v (1492); f. 219v (1493); f. 234v (1494).

${ }^{48}$ LC, f. 16r (31 August 1484).
} 
punishment of the 'kaak'. ${ }^{49}$ Judging by the oerveden register, Tade returned unauthorised later that year. She was put in prison and on the 'kaak', and was now made to swear to stay at least ten miles from the town, on punishment of losing an ear. ${ }^{50}$

Six years later, in 1490, her name appears in the jaarkeur register. Three men stood surety for her and promised that she would pay the town 20 hern $\mathrm{lb}$. in two terms. ${ }^{51}$ The first instalment would be paid 'wanneer sie ynkompt' ('when she enters [Kampen]'), the second a year later. But it appears that she decided against coming back, as a note was added later, stating 'sie is toch niet inkomen' ('she has not returned after all'). ${ }^{52}$ There are also entries in the jaarkeur lists in the town accounts of 1491, 1492 and 1493 (but not in 1494), obviously keeping open the option of her return for a few years after her representatives had renegotiated it. ${ }^{53}$ In this case, then, the exile did not arrange her own return, but it was arranged on her behalf by three middlemen. Why she decided not to return to the city after all remains unknown. Perhaps 20 hern $\mathrm{lb}$. was too much for her in the end.

This is not the only case in which it is specifically mentioned that others stood surety for a debt of an exile who had apparently not yet returned to arrange a repayment plan themselves. In the very first entry in the register, it is noted that Henric Aerntsz would pay his first term between now and 'sijnre incompst': his entry. ${ }^{54}$ In 1490, too, a debtor made his first payment 'doe hie yn quam': when he entered. ${ }^{55}$ In 1491 a mother helped arrange the return of her daughter by promising the guarantor her daughter's hooded cloak as security 'als sie ynde stad komet': when she enters the town. ${ }^{56}$ Such pieces of evidence are, however, scarce. In most cases it is stated that the first term needed to be paid before a certain date, and there is no mention of this first payment being a condition for the return. In most cases it was the debtor themselves who was named first in the

${ }^{49}$ LC, f. 16v (in September (between 9 and 15) 1484).

${ }^{50}$ Reg, p. 19 (1484).

${ }^{51}$ It is possible that Taede returned to Kampen before 1490 and subsequently incurred a 20 hern $\mathrm{lb}$. fine, as this is otherwise the only case on record where an exile pays to return after a banishment punishment.

${ }^{52}$ Reg, p. 403 (1 July 1490).

${ }^{53}$ SR, f. 192v (1491), f. 205v (1492) and f. 219v (1493).

${ }^{54}$ Reg, p. 372 (25 December 1465).

${ }^{55}$ Reg, p. 403 (25 September 1490).

${ }^{56}$ Reg, p. 405 (1491, after 15 July). 
entry. This suggests that they negotiated with the magistrates directly, though initial mediation by others may have taken place before, seeing that exiles were not allowed to enter the city and they may not all have had the means or ability to write a letter. ${ }^{57}$

That the role of others was quite important in restoring a person to the town community is suggested by the lay-out of most of the first few entries in the register. In those the pledges are mentioned first and appear as the main actors in the agreements reached. The three guarantors for Henric van Leyden, for example, promised together and each for all that Henric's 20 hern lb. debt would be paid in five terms. ${ }^{58}$ After the first few entries, the lay-out changes and from then on, the entries usually mention the debtor first. It is likely that pledges played a similarly deciding role in many of the other cases, even although this is not specifically mentioned. For one, guarantors were necessary to ensure payment. The debtors in question had displayed behaviour, that is to say they failed to pay or fled the town to avoid payment or even appearing in court, that made them untrustworthy and unreliable partners from the point of view of the town council. The debtor's social network was therefore a deciding factor in the magistrates' decision to allow someone to return and to trust that the debt would be paid. This confirms that the functioning of law and justice depended on cooperation and consensus within a set of complex social relations between magistrates, offenders and their networks. ${ }^{59}$ In Kampen there is evidence that the pledges at times paid off part of the debt. By standing surety, they put their reputation on the line. ${ }^{60}$ There are a number of examples in which the debtors promised to keep the pledges 'schadeloos', that is to say not to subject them to pecuniary liability, by putting up their property as security. These entries also confirm that at least some of the exiles had not only a social network, which made them eager to return to Kampen, but also property. The already mentioned Henric Aerntsz, for example, set his house, garden, horses and cows as security. A wagoner offered all his good horses and his wagon. ${ }^{61}$

\footnotetext{
${ }^{57}$ Maurer ('Erzwungene Ferne', 214) also notes that the records show that others put in requests for the return of exiles.

${ }^{58}$ Reg, p. 372 (1465).

${ }^{59}$ Blauert, Das Urfehdewesen, 68-9.

${ }^{60}$ It is not clear why the guarantors were not made to pay the remainder of the fines in the cases mentioned above.

${ }^{61}$ Reg, p. 410 (November 1494).
} 
Standing surety were often family members (mostly fathers and brothers), masters or fellow tradesmen. There are few women, but that is not unexpected. ${ }^{62}$ More often women (usually wives, but also mothers) promised to keep the pledges harmless by putting up collateral. ${ }^{63}$ In the case of Henric Aerntsz, two of his brothers stood surety for him, in addition to one other man. The Rhine skippers in particular appeared regularly in the jaarkeur records as pledges for their colleagues. A good example of this is when Herman Schuefstake, a Rhine skipper who had been banished following a wounding, needed help: five of his pledges were also Rhine skippers. ${ }^{64}$ Four of the guarantors of Derick Geertsz, a basket maker who had committed a wounding at night, were colleagues of his. ${ }^{65}$ In many cases, though, it is unclear what the relation between pledges and debtor was. It is likely that fellow guild members played an important role, but few guild records survive for the middle ages. A more thorough prosopographical and relational analysis may be able to throw more light on this, but falls outside the scope of this study. Schuster, too, stressed the importance of an offender's social network. In Konstanz, family members had a joint responsibility to pay fines. High fines sometimes proved too much of a burden for someone with a small or non-existent social network. The system of penalties in Konstanz, as that in Kampen, certainly favoured the rich and well-connected. ${ }^{66}$ In medieval Venice, inmates could be let out of prison if they could provide pledges and a promise that the debt would be paid in annual instalments. This was only offered to those who were expected to have a steady income. ${ }^{67}$ So elsewhere, too, social networks were vital to debtors and their ability to maintain part of the town community.

Some men appear as pledges on a number of occasions and in several sources. A number of them were publicans, that is to say men with a profession that brought them into contact with many people, and especially those involved in violence as a result of brawls. One of these men was Gijsbert Blanckert, who appears as a guarantor several times, both in the jaarkeur and in the Liber Testium, and over a long period (between 1466

\footnotetext{
${ }^{62}$ One example is Alijt Lodewich's wife, Reg, p. 374 (1466).

${ }^{63}$ For example, Reg, p. 377 (1482), p. 384 (1481), p. 387 (1485).

${ }^{64}$ Reg, p. 404 (December 1490).

${ }^{65}$ Reg, p. 395 (27 December 1488).

${ }^{66}$ Schuster, Stadt vor Gericht, 257, 315.

${ }^{67}$ Geltner, The Medieval Prison, 15, 60.
} 
and 1491). He also figures as a pledge in the town accounts. ${ }^{68}$ Another who features often is Berent Jansz, the publican of the 'Inden Witten Aern' ${ }^{69}$ From 1489 at the latest the town hired two 'voirspraken', defenders: Wicher (no last name given, but probably Rensinck $)^{70}$ and Geert Wissinck. They were paid 28 and 12 pounds per annum respectively. ${ }^{71}$ Wissinck, for example, also appears regularly in the Liber Testium and the town account as a guarantor, though never in the jaarkeur. ${ }^{72}$ It may be that, in cases of banished debtors, the magistrates required pledges who were willing to risk their reputation and who could speak from personal experience, rather than guarantors on the town's payroll.

In a few cases no guarantors were found, but the magistrates were amenable nonetheless. One of these is from 1480 and the debtor was a foreigner: Johan de Leke of Kalkar, but living in Hamburg. Though there is no mention of his crime in the entry, his fine ( 50 hern lb.) suggests that he had committed a wounding at night. ${ }^{73}$ This is confirmed by the fact that his probable opponent, Johan Mesmaker, was banished for wounding him at night in the same year. ${ }^{74}$ De Leke himself was apparently not banished, but arranged to pay his large fine. Instead of providing guarantors, De Leke swore an oath to pay his debt in ten instalments, an oath which was signed and sealed with his own seal, suggesting that he was a merchant. The fact that he was allowed to swear, rather than being required to find guarantors, also indicates that he was considered trustworthy, though one would think that a merchant should have had no difficulty in finding people to stand surety for him. It appears, however, that De Leke did not return to pay off his fine: the entry remains undeleted, as do those recording the annual instalments in the lists in the town accounts (see Fig. 5.2) ${ }^{75}$

${ }^{68}$ Reg, pp. 373, 378, 382, 385, 386, 394, 404; LT, ff. 2v (2x), 36r, 72r, 75r, 132r, 160r; $\mathrm{SR}, \mathrm{f}$. 182v. For more information on Blankert and his tavern as a legal space used for business transactions, see Frankot, 'Legal business outside the courts', 181-2.

${ }^{69}$ For example, Reg, p. 392 (1486), p. 406 (1492), p. 420 (1499).

${ }^{70}$ Rensinck appears regularly in the town accounts, for example eight times as a pledge in 1490: SR, ff. 182v-183v.

${ }^{71}$ SR, f. $167 \mathrm{r}$ (1489); f. 179v (1490).

${ }^{72}$ For example, in 1490: LT, ff. 160r (2x), 160v (2x), 16lr (2x); SR, ff. 181v (1x), 182r $(3 \mathrm{x}), 182 \mathrm{v}(5 \mathrm{x}), 183 \mathrm{r}(2 \mathrm{x})$.

${ }^{73}$ Reg, p. 384 (1480).

${ }^{74}$ Reg, p. 128 (1480).

${ }^{75}$ From 1484 onwards the accounts note the payment due for that year and of those still remaining for the previous years. There are no more entries after 1490, the year in which the debt should normally have been paid off. It appears that the magistrates gave up hope that 


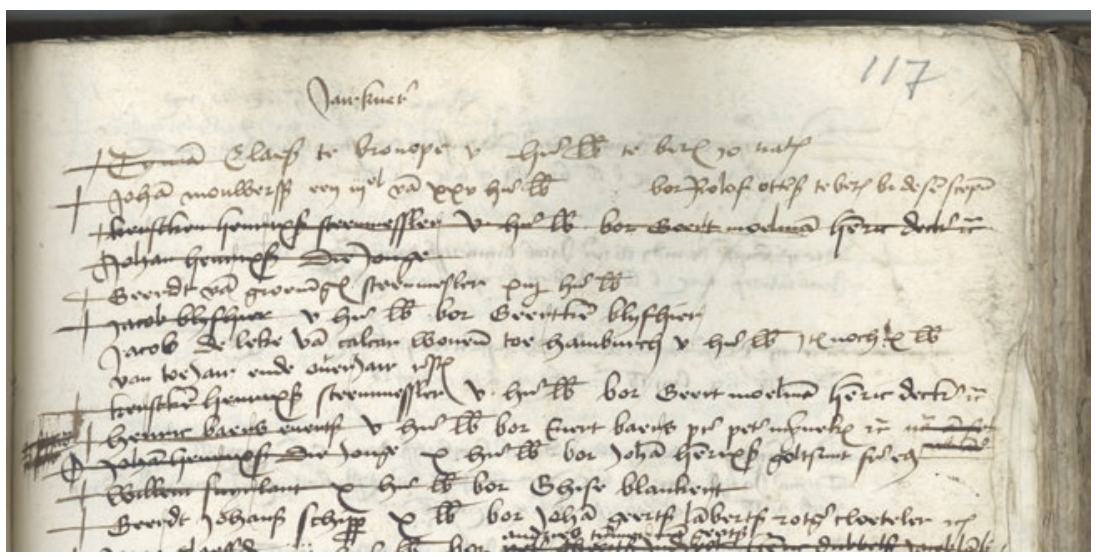

Fig. 5.2 Detail from a page from the town accounts listing the annual jaarkeur payments, with Jacob die Leke's entry as the only one not deleted (SR, f. 117r (1485)). (C) Stadsarchief Kampen, Nederland/(C) City Archives Kampen, the Netherlands)

The other three men who swore an oath also did not pay off their debt, though one of them, a man from Alkmaar living in Danzig whose case was entered in 1493, does appear to have paid once, in 1496, perhaps on his next visit to the town. ${ }^{76}$ This does suggest that the swearing of oaths alone was not a very effective way of securing someone's cooperation, as opposed to the use of guarantors.

The Kampen magistrates adhered very strictly to the by-laws when meting out fines in the lower court. They never once, for example, deviated from the set $100 \mathrm{lb}$. (25 hern lb.) fine for a wounding during the day and $200 \mathrm{lb}$. (50 hern lb.) for a wounding at night. This is contrary to the legal practice in Konstanz where the magistrates were more flexible in meting out fines for lighter offences, but adhered strictly to the law with regard to the most serious crimes. ${ }^{77}$ The Kampen courts were much more flexible when it came to agreeing terms for the payment of fines (as they were when passing judgement in the higher court). Presumably in such cases

De Leke would return after that date. SR, f. 83r (1481); f. 91r (1482); f. 99r (1483); f. 107r (1484); f. 117r (1485); f. 129r (1486); f. 140r (1487); f. 154r (1488); f. 168r (1489); f. $180 \mathrm{v}(1490)$.

${ }^{76}$ Reg, p. 407 (Oct 1493). The other two are on p. 386 (1484) and p. 393 (9 Jun 1487).

${ }^{77}$ Schuster, Stadt vor Gericht, 207. 


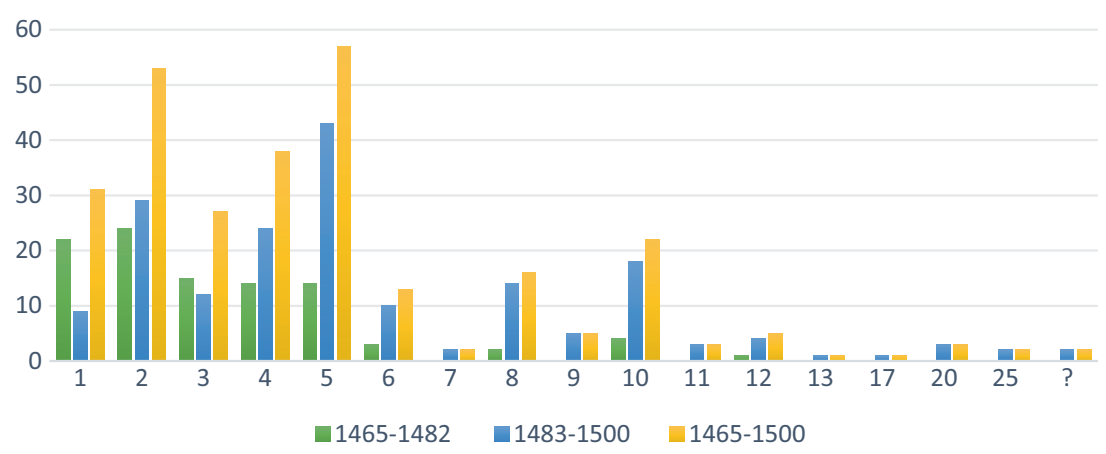

Fig. 5.3 Number of debtors per amount of jaarkeur terms

the personal situation of each of the debtors was taken into account and terms were based on everyone's ability to pay. This meant that, though most debts were paid off in 1-5 terms, some people were allowed 10, 12 , 20 or even 25 terms (see Fig. 5.3).

Berent van Asbeeke, for example, was given 20 years to repay his 20 hern lb. fine in 1498. Dirck Petersz was also allowed 20 years to pay off his 50 hern lb. fine in 1499, though a condition was added that he would have to pay his debt immediately if he would receive an inheritance within this period. It appears, however, that Dirck's father, who stood surety, survived for another 20 years, and Dirck completed all 20 of his terms. Whether Berent van Asbeeke did as well is not clear. There is a cross in front of his name which suggests that he paid his dues, but there is only one note on a payment of 4 hern $\mathrm{lb}$. in 1501 .

In general, debts were paid off in full. The magistrates may have been flexible in agreeing terms, but they did expect the full fines to be paid. There is little evidence of discounts for the poor, for example, like there was in medieval Ghent in composition payments. ${ }^{78}$ The amount mentioned in the jaarkeur register does not always fully correspond with that in the banishment register, but these discrepancies appear especially at the start of the register and may be the result of a different way of registering the remaining amount to be paid. It may be that in these cases the first payment, perhaps made on arrival, was deducted from the amount due.

\footnotetext{
${ }^{78}$ Van Eetveld, 'Vrouwencriminaliteit', 176. In fourteenth-century Zürich, offenders were fined if they asked for a discount from their fines. Burghartz, Leib, Ehre und Gut, 88-9. For a few exceptions, see note 15 .
} 
After 1482, there are virtually no more discrepancies. There is one case in which there may have been a discount, as there is a significant discrepancy between the fine and the amount paid according to the jaarkeur. In 1472 Willem Blijfher was banished for a wounding at night. He was twice caught in town after this, meaning that he ended up needing to pay off a $360 \mathrm{lb}$. fine. In the jaarkeur register we find his father Jacob and mother Geertken promising to pay his $240 \mathrm{lb}$. fine in 12 instalments. We can then follow the annual payments in the town accounts: in 1475 Jacob paid 'for his son', in 1476, 1477 and 1478 Willem paid himself, with his parents standing surety. In 1479 and 1480 Geertken paid, and from 1481 and 1486 Jacob Blijfher picked up the bill with Geertken standing surety. ${ }^{79}$ This was not Willem's father, however, but perhaps a brother by the same name, as other sources suggest that Jacob had died by $1479 .{ }^{80}$ One of the Jacobs had also been banished for a wounding in 1467, but there is no record of how this fine was paid off. ${ }^{81}$ Of course, if Jacob Blijfher had been able to pay his fine in one go, he may also have paid the first $120 \mathrm{lb}$. of Willem's fine off when his son returned. If that were in fact true, there was no discount in this case either. If there was, there is no clear evidence that it was granted. Among the entries there are only two which make mention of an exoneration of debt ('remissum'). Johan Berntsz in 1492 had been given 25 terms to repay a 50 hern $\mathrm{lb}$. fine, but it appears that even that was too much. ${ }^{82}$ One of his guarantors paid an instalment in 1500 and another was paid by both his guarantors in 1502 , but otherwise it seems his debt remained unpaid. It was not until after 1502, though, that the magistrates decided to acquit him 'ob paupertatem'. Johan Lubbertsz, a Rhine skipper, was also due a 50 hern $\mathrm{lb}$. fine. Eight pounds were paid in cash by someone else, whereas the rest would be fulfilled in seven instalments at six pounds. The administration shows that the first five of these were met, but the last two were not, and the remainder was exonerated. ${ }^{83}$

The administration of the jaarkeur appears to have changed slightly around 1482-83. After this date there were fewer mistakes with regard to deleting the relevant entries in the banishment register. In addition, part of the entries after 1483 mention the debtors' crimes, on which their fine

\footnotetext{
${ }^{79} \mathrm{SR}$, ff. 29r, 38v, 47r, 57r, 66v, 75r, 83r, 91r, 99r, 107r, 117r, 129r.

${ }^{80}$ Geertken was arranging the inheritance of their father with two of her daughters in 1479 and 1480 respectively. SAK, RA, no. 75, f. 94r (24 May 1479) and f. 102v (19 January 1480).

${ }^{81}$ Reg, p. 109 (1467).

${ }^{82}$ Reg, p. 406 (1492).

${ }^{83}$ Reg, p. 395 (22 November 1488).
} 
had been based. These small changes are most likely the result of a different clerk taking over the administration: from 1482 the jaarkeur entries are in a different hand. Around the same time, there may have been a slight alteration in policy (whether conscious or not) which is reflected in the jaarkeur register. This alteration was to do with the number of instalments agreed, which was on average clearly higher in the second half of the period than in the first (see Fig. 5.3). From 1465-82 there was an average of about 3.2 instalments per arrangement, where the average between 1483 and 1500 was 5.5 . This can only partly be contributed to the higher average fines recorded in this register in this period (the fines repaid were on average 4 hern $\mathrm{lb}$. higher in the second half of the period). ${ }^{84}$ Lower annual payments were a more significant factor. Between 1465 and 1482 the average payment per year was just over 11 hern lb., whereas that between 1483 and 1500 was c. 7.5 hern lb. Whether this was because the debtors had less money available to them towards the end of the century or because the council became more lenient when arranging terms, as said either consciously or not, remains unclear. It is notable that there were also nearly twice as many offenders seeking to arrange to pay in terms in the second period. As has been pointed out before, there was slight economic decline in the fifteenth century, and some Kampen officials were receiving less pay later in the fifteenth century than before, but it is unclear whether these numbers can have anything to do with that. ${ }^{85}$

There are not many other towns where the practice of payment of fines in instalments has been analysed, most likely because of a lack of sources. Another town which does also boast such an administration is Konstanz. The magistrates there were also flexible in their dealings with debtors, though most fines appear to have been paid much more quickly than they were in Kampen. Of 384 fines, 219 were paid within a year, whereas in Kampen debtors paid in annual instalments, making it much more unusual for anyone to pay off a debt within a year. Like in Kampen, though, the Konstanz magistrates looked at individual cases and did allow offenders to take as long as they needed to redeem their fines and were not too strict when it came to paying on time. ${ }^{86}$ There is some evidence that in Konstanz

\footnotetext{
${ }^{84}$ In the period $1465-82$, the average fine that was repaid was 26.53 hern $\mathrm{lb}$.; in the period $1483-1500$ it was 30.5 hern $\mathrm{lb}$.

${ }^{85}$ For example, earlier in the century the 'stokmeester' received 191/2 hern lb. per annum, later only 15 hern lb. LD, f. 170r (1432; 1451), f. 218v (1468; 1483). See also SR, f. 179v: Berent de stokmeister xv lb. (1490).

${ }^{86}$ Schuster, Stadt vor Gericht, 233-4; Schuster, 'The age of debt?', 46-7.
} 
the magistrates sometimes renegotiated terms with debtors and asked for pledges, something which cannot be verified with regard to Kampen. Schuster argues that through 'patience, meticulousness, force and persistence' the Konstanz magistrates succeeded in claiming most of the fines due to them: at least 75 per cent was paid off in full, whereas no more than 10 per cent did not pay anything at all. ${ }^{87}$ The latter were mainly those that fled or left the city. ${ }^{88}$

In Kampen, too, a large majority of debtors who chose to return to or remain in town redeemed their fines in full. Only 12 of 316 entries (3.8 per cent) were not deleted. We can therefore conclude that its magistrates also implemented a most successful system to entice its debtors to pay. In Konstanz the council ensured payment in various ways. First of all, a debtor's oath to pay entailed that a failure to pay could, in principle, result in coercive measures (Zwangsverfahren) being initiated against the debtor, which could eventually lead to a loss of life and goods on charges of oath breaking. The use of pledges and guarantors also provided important incentives to pay, both for the debtors and for their guarantors. Finally, Schuster argues, the system also functioned because the town magistrates treated their debtors with patience and trust. ${ }^{89}$ In Kampen there is no specific evidence of oaths being sworn by debtors when they arranged the payment of their fines, but the fact of the administration of the arrangements does suggest a binding contract between city and offender. The other factors mentioned by Schuster are valid for Kampen too.

A relation of debt automatically created a bond between creditor and debtor, in this case between the magistrates and the offender. ${ }^{90}$ This means that an arrangement with a higher number of instalments may have had a positive effect on their relationship: the offender may have felt bound by the debt to improve his or her behaviour for the time being. Despite this potential effect, there are a few cases in which people offended again while still paying off a debt. In 1494, for example, wagoner Evert Twenth was banished for a wounding at night in the town's bath house. He was soon able to negotiate his return, with his father, brother and two others as guarantors, and his horses and wagon as surety. He arranged to pay his $\mathbf{5 0}$

\footnotetext{
87 'Geduld, Sorgfalt, Nachdruck und Hartnäckigkeit': Schuster, Stadt vor Gericht, 243; ibid., 243-5.

${ }^{88}$ Ibid., 246.

${ }^{89}$ Ibid., 255-6.

${ }^{90}$ Schuster, 'The age of debt?', 41,45 .
} 
hern $\mathrm{lb}$. in eight instalments. But after having paid three instalments in 1494, 1495 and 1496, his payments stalled. The reason was that Twenth had committed another wounding, this time during the day on one of the dykes, and he was banished again. Despite his previous outstanding debt, and his lowly profession, Twenth was able to negotiate a second return in 1498. Again, eight terms were agreed upon and his brother and another man stood surety. This second fine, of 25 hern lb., appears to have been paid off in full, but the first one seems not to have been. One more payment was registered in 1501, but a note 'dubium' was added in the margin, suggesting that the scribe was not entirely certain whether the debt was paid off, or not. ${ }^{91}$

A similar case was that of Henrick Scherynck who was convicted twice in the same year: first for trying to stab someone with a knife and allowing dice games to be played in his house. He arranged to pay for the fines, $22 \frac{1}{2}$ hern lb. in total, on conviction in 1497 . He paid the first instalment before he was banished for a wounding at night later in the same year. $\mathrm{He}$ arranged for the payment of this fine in 20 instalments and paid off this fine, but he too appears to have missed some of the payments to redeem the first fine and this remained undeleted. ${ }^{92}$ Unfortunately, we do not have the town accounts for these years, so it is not possible to check these to confirm whether or not the first debts in these cases were paid off or not. It would also have been interesting to see how these two simultaneous debts were registered. It may be that the amounts were added up and that actually both were paid off at the same time.

These two examples are useful in that they show that the magistrates were amenable to even allowing people that were already in debt, and twice banished for the non-payment of a fine to negotiate a financial arrangement and a return to Kampen, without any apparent further repercussions. Other cases also show that banishments for the non-payment of a fine did not lead to a decrease in people's ability to act as respectable members of the community. For example, Johan Borre had been banished in 1465 with two others for a wounding by day. He negotiated his return in 1466. One of his companions, Henric Palmer, also came back to Kampen, but not until $1478 .^{93}$ Borre was one of the people standing surety for him at that time. In addition, Borre can be found as a debtor

\footnotetext{
${ }^{91}$ Reg, pp. 145 (1494), 150 (1497), 410 (1494), 416 (1498).

${ }^{92}$ Reg, pp. 151 (1497), 414 (1497), 418 (1498).

${ }^{93}$ Reg, pp. 105 (1465), 373 (1466); p. 382 (1478).
} 
and creditor in other sources. ${ }^{94}$ Not every offender can be found in other sources. This may be because they had names that are too non-specific, or because they had a social position which restricted their financial and legal activities. A servant will have left behind less footprints in the sources than their master.

An unusual case is that of Henric van Leyden. Henric had been banished in 1465 for a wounding and renegotiated his return in the same year. Three of his guarantors were dyers, so he may have been a dyer himself. The debt appears to have been paid off in full in five instalments, the final payment probably taking place in $1470 .{ }^{95}$ But in the same year that Van Leyden had been banished and returned, in May, Henric van Leyden was also convicted of counterfeiting coins. He swore an oervede oath, was branded on his cheek and banished at a distance of five miles. ${ }^{96}$ However, in 1466 a Henric van Leyden was wounded, and a man by the same name appears regularly in the sources in the $1470 \mathrm{~s} .{ }^{97} \mathrm{~A}$ servant of his was, moreover, wounded in $1475 .{ }^{98} \mathrm{~A}$ likely explanation would be that there are in fact two men by the same name. But there is no differentiation added to the names anywhere suggesting that they were indeed different men. If there was indeed only one man, this would suggest that he was redeemed by the magistrates despite his branding and banishment for life, and able to return to being a well-functioning member of society.

An important difference between legal practice in Konstanz and Kampen is that in more than half of Konstanz cases the punishment meted out by the court was transferred into another. Fines in particular were paid off through labour, or banishments and jail sentences were changed into fines or labour for the city (mainly working for the town building master), but other exchanges took place as well. ${ }^{99}$ Conversely, in Kampen the nonpayment of fines resulted in banishment, but in most cases this was not an alternative penalty. ${ }^{100}$ In Konstanz offenders tried to prevent being exiled if they could, but Kampen offenders did not have the option of working

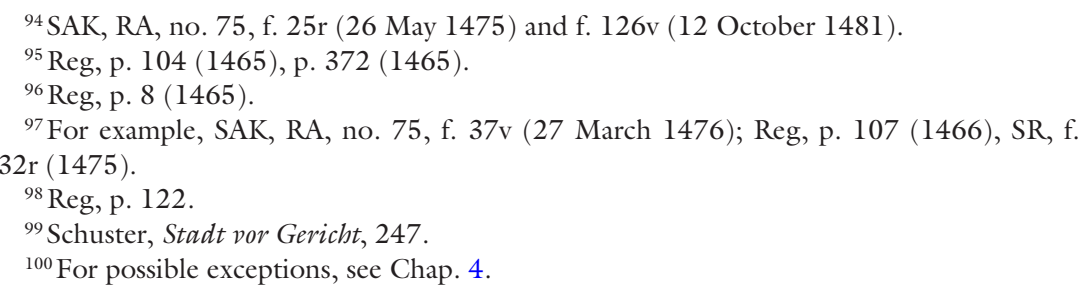


off their debts through labour. As a result, more people were banished from Kampen each year than from Konstanz. ${ }^{101}$

Considering the evidence, it appears that the town magistrates did not generally banish offenders unable to pay their fines to get rid of them altogether. They showed themselves amenable in allowing debtors to pay off their debts in as many yearly instalments as necessary. They appeared to have made no difference in their treatment of those who had fled justice, those who had failed to pay their fine and had been banished, and those who arranged for a payment plan immediately. This practice ensured that Kampen inhabitants who had families, relations and an occupation within the town could remain, and were able to earn an income by continuing to work. In addition, they could use their personal networks to generate money. The magistrates did insist on payment, though, and if none was forthcoming, unless in very extraordinary circumstances, people were ousted from the community. On the other hand, there is no evidence that any of the debtors who had already arranged to pay back their debts were banished again or declared an exile when they failed to meet these payments. There are 12 debtors in the jaarkeur register whose entries were not deleted and for whom at least some of the payments were not indicated as having been made. As noted above, four of these were by men who had sworn an oath. We also have some of the relevant town accounts which include comments on the non-payment of these instalments, such as 'restis de multis terminis' or 'restis noch van voele jaire'. After about ten years of non-payment the magistrates appear to have given up, as the debtors then generally disappear from the record. A number of them were not originally from Kampen, so they may simply never have returned to Kampen for whatever reason, or only irregularly (some did do some of the payments). Of others it is unclear what happened. But there is no evidence that any of the 12 were declared banished again.

Those unable to pay their fines who did not have strong enough connections to the town and its community to want to make an effort to make any payments did most likely not come back to Kampen, or they were not allowed to return. It is quite possible that the fines for violent offences

${ }^{101}$ In Konstanz between 1444 and 1453, 50 offenders (so on average five a year) were either banished or imprisoned ( 33 as a sole punishment, 13 in addition to a fine and 4 in addition to labour). These are punishments that were actually undertaken, and this number disregards any banishments meted out for more serious crimes. Schuster, Stadt vor Gericht, 247 (table). The population of both towns is considered to have been approximately the same in the fifteenth century: 6-8000. 
were deliberately high so the town could easily rid itself of undesirables if they committed an offence, and were unwilling or unable to redeem themselves for their crime. The town magistrates were probably happy to be rid of such people, who had broken the law, often by conducting violent offences, had no particular bonds to the city and had nothing to contribute financially. In addition, their failure to pay the fine, and, as such, their debt to society, may also have been considered in the context of their morality. In medieval society, debt and morality were considered to be linked, and the failure to pay a debt was considered to be deserving of punishment in itself. The question whether the same can be said for fines is discussed in the final section of this chapter.

\section{Debt, Fines And Morality}

Medieval man was linked to others through many credit relations, especially in towns. Such relations were put under strain when individuals failed to pay their debts, and solutions were sought in ecclesiastical and civil regulations for the enforcement of minor credit. Initially, it was the church courts which provided such solutions, and creditors used canonical procedures to pressurise debtors into paying. The reason why church lawyers and courts felt such issues were part of their remit was that unpaid debts were considered as breaches of faith between two Christians who had entered into an agreement. The obligation to repay a debt was seen as sacred. So, commerce was viewed as an intricate part of a Christian moral society which was based on trust and charity. A failure to pay damaged this trust and it revealed a lack of charity on the part of the debtor. It was the duty of Christians to correct the sin of defaulting debtors. ${ }^{102}$

The remedy offered by the church was excommunication for debt. This excommunication acted as a coercive measure to get Christian debtors to pay, especially concerning privately recorded debts and sales on credit. Its use in much of Europe from the thirteenth to the sixteenth centuries suggests that it was considered to be useful by creditors. This may partly be because, until the end of the middle ages, civil courts were unwilling or unable to provide similarly effective, and relatively cheap, solutions. By the fifteenth century, increasingly more elite observers criticised the use of excommunication for debt. At the same time, secular courts contested the ecclesiastical jurisdiction over a number of questions, including those of

${ }^{102}$ Lange, Excommunication for Debt, 4, 41, 46. 
contract and credit. ${ }^{103}$ Tyler Lange has concluded that in the diocese of Utrecht, to which Kampen belonged, civil courts may have developed secular solutions in the absence of an adequate supply of ecclesiastical justice'. ${ }^{104}$ Elsewhere, such as in England and the Italian city states, imprisonment for debt was introduced as an alternative to excommunication already in the fourteenth century. ${ }^{105}$

Even if excommunication for debt may have been uncommon in the Utrecht diocese, the excommunication and punishment of defaulting on debts in general were a clear indication of the strong links between debt and morality. As Lange has stated 'excommunication for debt confirmed that credit was at once a moral, social and economic quantity that reflected the state of one's soul, one's social status and one's economic position'. ${ }^{106}$ Ireland has called debt a 'form of sin or social offence which merited punishment'. ${ }^{107}$ Of course, one can question to what extent issues of morality influenced creditors, who may mainly have been looking for an efficient remedy for their practical problems concerning minor credit. Such remedies were, for example, offered by the charter of the town of Haarlem from 1245, where defaulting debtors could be held in town arrest for two weeks before being handed over to their creditors. These were then allowed to keep their debtors in custody until arrangements had been met for the payment of the debt. ${ }^{108}$

In Kampen, there are no specific by-laws in the Boeck van Rechte or the Gulden Boeck concerning debt. There is evidence of cases being settled in court concerning debt, such as in the Liber Causarum, and there are witness testimonies in the Liber Testium concerning sales and debts resulting from them. ${ }^{109}$ But there is no evidence from legal practice of banishment being used in cases of private debt, although, as we have seen, some people were banished for defaulting on debts to the city (see Chap. 2). As such, we do not get a clear sense of the perceptions of debt in general on the part of the Kampen magistrates or the population.

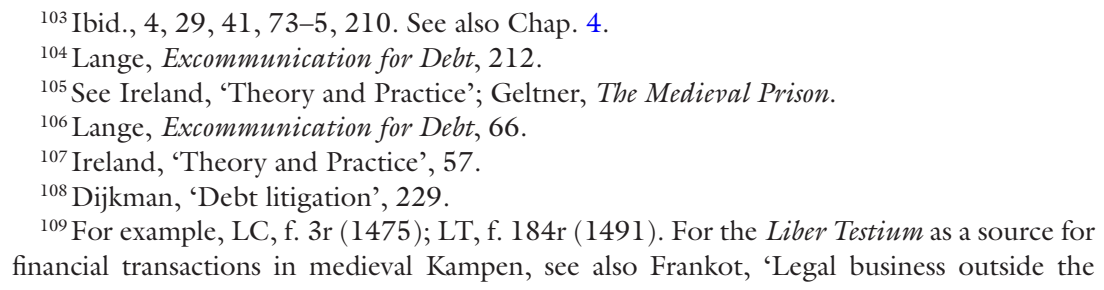
financial transactions in medieval Kampen, see also Frankot, 'Legal business outside the courts'. 
We can ask to what extent the non-payment of fines was considered to be similar to defaulting on debts. When the by-law laying down fines for illegal returns to the city after a banishment differentiates between those ousted for failing to pay a fine and debtors, this suggests that the two were considered to be related. But seeing that debtors only had to pay half the fine compared to the individuals who did not pay their fines, it seems the latter were judged more harshly. Of course, this may be because of the combination of their fineable offence and the fact that they did not pay, whereas the debtors were only guilty of defaulting on their payment. Both were able, in principle, to redeem themselves quite simply by paying their dues. There were no further obvious consequences, though it may be that the magistrates would be wary of renting out town properties again to those who had defaulted on payments in the past. From the language used in the legal records, we get no sense of any links between debt and morality, as we do concerning certain behaviour in the final quarter of the fifteenth century (see Chap. 4). This does not mean that such links did not exist, as the banishment records are very concise, but that there simply is no record of it.

At the same time, banishment was a serious measure that was otherwise meted out to sexual offenders in particular. This in itself might indicate that the magistrates did consider a failure to pay a fine in the context of a person's morality. As members of the town community, people had a responsibility to uphold the law. As suggested in Chap. 4, a failure to do so, and then not facing the consequences by paying a fine, could be considered a breach of faith. Interesting in this context is the fact that some offenders appear to have arranged terms for payment directly following their trial, whereas others apparently had not. It may be that the magistrates expected people to come forward themselves rather than them offering a financial arrangement as a possibility to everyone. If an offender did not take responsibility for paying off their fine, this was their own fault and they should bear the consequence, and this consequence was exile.

In conclusion, redemption after a banishment was possible for most offenders, though the route to redemption might have varied. Individuals who had been banished outright could negotiate a return after a certain amount of time unless they had been cast out permanently. It is unclear, though, how it was decided when someone could come back. This may have depended on the culprit's reputation, status and crime, but also perhaps on the efforts of their social network. It appears that a banishment did not have negative repercussions on someone's ability to function 
normally after their return. The offence was apparently amended through the banishment. To those banished for failing to pay a fine, redemption could be effected by arranging the payment of the amount due. Only about a third of outcasts chose this route; the rest remained banished. Both groups included different social classes. The Kampen magistrates appear to have been happy to set up financial arrangements and showed themselves flexible in offering terms. Fines generally needed to be paid off in full, but exceptions were made, and no one was banished again when terms remained unpaid. But for the most part offenders paid their dues in full and an effective system to guarantee payments appears to have been in place. Vital to the reintegration of these outcasts were their relatives and friends, who stood surety and probably played an important role in early negotiations for a return. Although the magistrates appeared to have been happy to allow people to return, there is some evidence that suggests that they did consider it the responsibility of the offenders to come forward to make arrangements. This may have been considered part of the culprit's moral duty as a public debtor. There is no specific evidence that the nonpayment of fines was seen as a moral failure, but it is perhaps telling that defaulters were banished when banishment as a punishment was mostly meted out to those displaying immoral behaviour.

Open Access This chapter is licensed under the terms of the Creative Commons Attribution 4.0 International License (http://creativecommons.org/licenses/ by $/ 4.0 /$ ), which permits use, sharing, adaptation, distribution and reproduction in any medium or format, as long as you give appropriate credit to the original author(s) and the source, provide a link to the Creative Commons licence and indicate if changes were made.

The images or other third party material in this chapter are included in the chapter's Creative Commons licence, unless indicated otherwise in a credit line to the material. If material is not included in the chapter's Creative Commons licence and your intended use is not permitted by statutory regulation or exceeds the permitted use, you will need to obtain permission directly from the copyright holder.

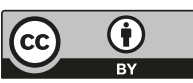

